Metal-metal bond formation of triplatinum cores with a silver(I) ion affording a heptanuclear cluster bearing four Pt-Ag bonds

Natsuki Yabune, Hiroshi Nakajima, Takanori Nishioka

\begin{tabular}{|c|l|}
\hline Citation & Dalton Transactions. 49(23); 7680-7683 \\
\hline Issue Date & 2020-06-21 \\
\hline Type & Journal Article \\
\hline Textversion & Author \\
\hline $\begin{array}{c}\text { Supplementary } \\
\text { files }\end{array}$ & $\begin{array}{l}\text { Supplementary information and Crystal structure data is available at } \\
\text { https://doi.org/10.1039/D0DT01227K. }\end{array}$ \\
\hline Relation & $\begin{array}{l}\text { The following article has been accepted by Dalton Transactions. This is the accepted } \\
\text { manuscript version. } \\
\text { The final, published version is available at } \underline{\text { https://doi.org/10.1039/D0DT01227K. }}\end{array}$ \\
\hline DOI & 10.1039/D0DT01227K \\
\hline
\end{tabular}

Self-Archiving by Author(s)

Placed on: Osaka City University Repository

Natsuki Yabune, Hiroshi Nakajima, Takanori Nishioka. (2020). Metal-metal bond formation of triplatinum cores with a silver(I) ion affording a heptanuclear cluster bearing four Pt-Ag bonds. Dalton Transactions. 49, 7680-7683. Doi:10.1039/D0DT01227K 


\section{Metal-metal bond formation of triplatinum cores with a silver(I) ion affording a heptanuclear cluster bearing four $\mathrm{Pt}-\mathrm{Ag}$ bonds ${ }^{\ddagger}$}

Received 00th January 20xx Accepted 00th January 20xx

\author{
Natsuki Yabune, ${ }^{a}$ Hiroshi Nakajima ${ }^{a}$ and Takanori Nishioka*a
}

DOI: $10.1039 / x 0 x \times 00000 x$

An $\mathrm{N}$-heterocyclic carbene triplatinum complex with two triply bridging sulfide ligands reacts with a silver(I) salt affords a heptanuclear complex. X-ray crystallographic analysis revealed that a silver(I) ion connects two triplatinum complexes with one of three Pt-Pt bonds of each triplatinum unit.

Since formation and cleavage of metal-metal bonds in transition metal clusters contribute their reactions, exploration for the nature of metal-metal bonding in such cluster compounds is one of the important subjects for utilisation of transition metal compounds. Energy levels of some of molecular orbitals concerning with metal-metal bonds in transition metal clusters are often close and then the metalmetal bond lengths are varied even for clusters bearing the same composition and framework depending on their environments in the solid states. However, we can easily estimate metal-metal bonding interactions using cluster valence electrons (CVEs) ${ }^{1}$ of transition metal clusters, especially for late transition metals. Trinuclear clusters bearing triply bridging sulfide ligands with 48 CVEs possess closed-shell configuration of metals with three metal-metal bonds contributing their less reactive feature. However, such clusters can be activated via reduction, for example, sulfide-bridged trinuclear complexes with $\mathrm{Cp}$-derivative ligands exhibit bond cleavage of one of the three metal-metal bonds upon 2electron reduction ${ }^{2}$ and show electrocatalytic ability for electrochemical reduction of $\mathrm{CO}_{2}$ affording oxalate. ${ }^{3}$

We previously reported synthesis and structure of triplatinum sulfide cluster bearing bidentate $\mathrm{N}$-heterocyclic carbene ligands (bisNHC-C2), [\{Pt(bisNHC-C2) $\left.\}_{3}\left(\mu_{3}-\mathrm{S}\right)_{2}\right]^{2+}$, in which two NHC moieties with a methyl substituent are connected with an ethylene bridge. ${ }^{4}$ In this paper, we describe synthesis and structure of a related triplatinum cluster with bidentate NHC ligands with a methylene bridge (bisNHC-C1), $\left[\{\mathrm{Pt}(\text { bisNHC-C1 })\}_{3}\left(\mu_{3}-\mathrm{S}\right)_{2}\right]^{2+}\left([1]^{2+}\right)$, and its reaction with silver $(\mathrm{I})$

\footnotetext{
a. Department of Chemistry, Graduate School of Science, Osaka City University, Osaka 558-8585, Japan. E-mail: nishioka@sci.osaka-cu.ac.jp.

Electronic Supplementary Information (ESI) available: Experimental, spectroscopic DFT calculations and X-ray crystallographic data. CCDC 1994350 and 1994351. See DOI: $10.1039 / \times 0 \times x 00000 x$
}

salt affording a $\mathrm{Pt}_{3}-\mathrm{Ag}-\mathrm{Pt}_{3}$ heptanuclear cluster.

The triplatinum complex, $\left[\{\mathrm{Pt}(\text { bisNHC-C1 })\}_{3}\left(\mu_{3}-\mathrm{S}\right)_{2}\right](\mathrm{OTf})_{2}$ $\left([1](\mathrm{OTf})_{2}\right)$ was synthesized by the reaction of a hydrosulfide complex, cis-[Pt(bisNHC-C1)(SH) 2$], 5$ and 2 equiv. of a chloro complex, cis- $\left[\mathrm{Pt}(\mathrm{bisNHC}-\mathrm{C} 1) \mathrm{Cl}_{2}\right]^{5}$ (Scheme1). Crystallographic analysis of $[1] \mathrm{Cl}(\mathrm{OTf}) \cdot 0.5 \mathrm{H}_{2} \mathrm{O}$ (Fig. 1) showed that two crystallographically independent complex cations exist in the unit cell. The complex cations are similar to each other and adopt the $C_{s}$ symmetry although there are two possible isomers $C_{5}$ and $C_{3 \mathrm{~h}}$ attributed to the orientation of the bis-NHC ligands (Scheme 2). The most sterically hindered Pt-Pt bonds (3.3233(8) and 3.3184(8) Å, red bonds in Fig. 1) surrounded by the four methyl groups of the two NHC ligands are longest in each cation. On the other hand, the least hindered Pt-Pt bonds (green bonds in Fig.1, 3.1824(7) and 3.2391(6) ̊̊) surrounded by the two methylene bridges of the two NHC

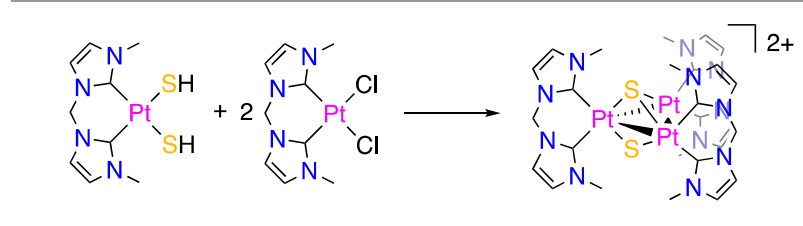

Scheme 1 Syntheses of triplatinum complex $[\mathbf{1}]^{2+}$

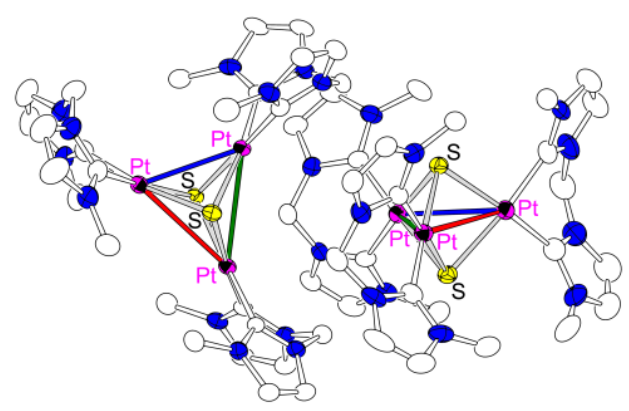

Fig. 1 Two crystallographically independent complex cations of $[\mathbf{1}]^{2+}$. The colours of the Pt-Pt bonds represent shortest (blue), medium (green) and longest (red) ones in each complex cation. Hydrogen atoms are omitted for clarity. 
ligands are longer than secondly hindered ones (blue bonds in Fig.1, 2.9734(9) and 2.9525(8) Å) near the two methyl groups and the methylene bridge. DFT calculation of $[1]^{2+}$ as an isolated form showed that the Pt-Pt bond surrounded by two methylene moieties of the two NHC ligands (3.261 $\AA$ ) is shorter than the other Pt-Pt bonds located near the methylene and two methyl groups (3.266 ̊) and the most hindered one (3.534 $\AA$ ) is with four methyl groups. These results showed that the crystal packing affects the $\mathrm{Pt}-\mathrm{Pt}$ distances.

${ }^{1} \mathrm{H}$ NMR spectrum of the triplatinum complex exhibited broad signals at room temperature (Fig. 2(b)) showing that the $C_{\mathrm{s}}$ and $C_{3 \mathrm{~h}}$ isomers of $[\mathbf{1}]^{2+}$ are in equilibrium in solution (Scheme 2) although only the $C_{\mathrm{s}}$ isomer was observed in the solid state as mentioned above. Platinum complex units bearing bis-NHC ligands with a methylene or propylene bridge show dynamic behaviour attributed to flapping motion of the NHC ligands, while those with an ethylene bridge exhibit no flapping motion and such NHC ligands with an ethylene bridge invert via $\mathrm{Pt}-\mathrm{C}$ bond cleavage at higher temperature. ${ }^{6}$ In the ${ }^{1} \mathrm{H}$ NMR spectrum at $243 \mathrm{~K}$ (Fig. 2(e)), sharp signals attributed to the isomers were observed and the $C_{\mathrm{s}}$ isomer exists 27 times more than the $C_{3 \mathrm{~h}}$ isomer estimated using the integrated intensities of the $\mathrm{N}$-methyl signals at 3.58 and $3.72 \mathrm{ppm}$ for the $C_{\mathrm{s}}$ and $C_{3 \mathrm{~h}}$ isomers, respectively.

Reaction of triplatinum complex $[\mathbf{1}]^{2+}$ with a half equiv. of AgOTf afforded a heptanuclear cluster $\left[\mathrm{Ag}\left\{[\mathrm{Pt}(\mathrm{bisNHC}-\mathrm{C} 1)]_{3}\left(\mu_{3^{-}}\right.\right.\right.$ $\left.\left.\mathrm{S}_{2}\right\}_{2}\right]^{5+} \quad\left([2]^{5+}\right) \quad$ (Scheme 3$)$. X-ray crystallography of [2] $(\mathrm{OTf})_{3}\left(\mathrm{PF}_{6}\right)_{2}$ (Fig. 3) exhibits that the cluster cation possesses a crystallographic 2-fold axis through the $\mathrm{Ag}(\mathrm{I})$ ion. The $\mathrm{Ag}$ centre binds to two platinum ions in each of the triplatinum

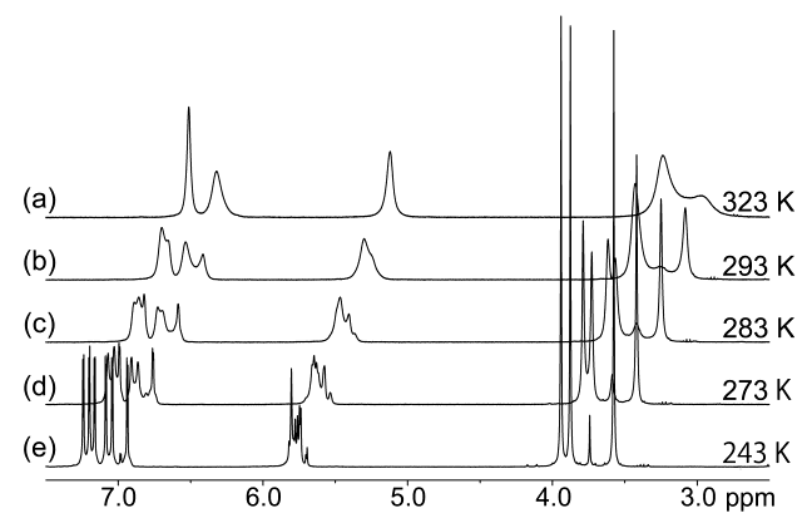

Fig. $2{ }^{1} \mathrm{H}$ NMR spectra of triplatinum complex $[1]^{2+}$ in $\mathrm{CD}_{3} \mathrm{CN}$ at (a) $323 \mathrm{~K}$, (b) $293 \mathrm{~K}$, (c) $283 \mathrm{~K}$, (d) $273 \mathrm{~K}$ and (e) $243 \mathrm{~K}$.
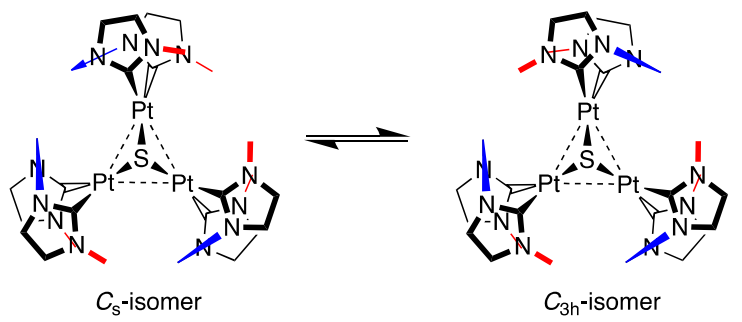

Scheme 2 Isomers of triplatinum complex $[\mathbf{1}]^{2+}$ interconverted via flapping motion of bisNHC ligands.

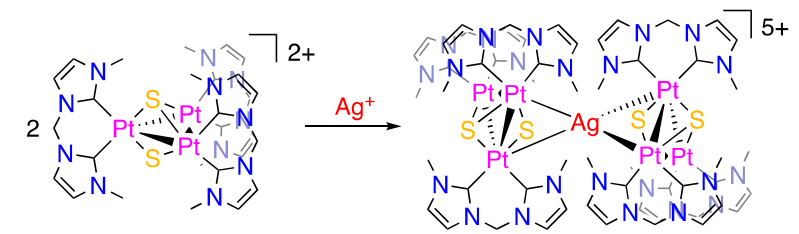

Scheme 3 Formation of $\mathrm{Pt}_{3} \mathrm{AgPt}_{3}$ heptanuclear cluster [2] ${ }^{5+}$.

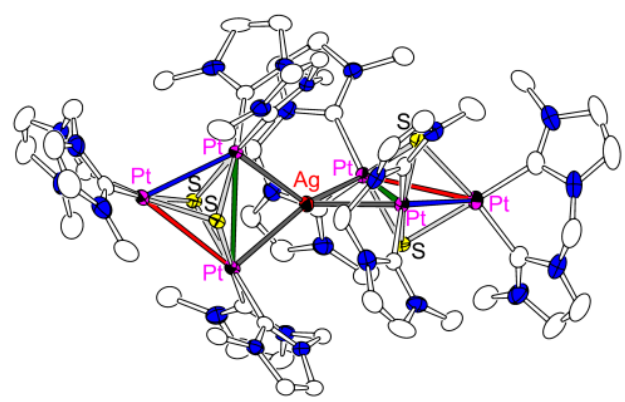

Fig. 3 Structure of cationic moiety of $\mathrm{Pt}_{3} \mathrm{AgPt}_{3}$ heptanuclear cluster [2] ${ }^{5+}$. Hydrogen atoms are omitted for clarity.

units to form four Ag-Pt bonds (2.7741(4) and 2.8139(3) $\AA$ )), which are shorter than the reported value $(2.9088(2) \AA)$ observed in a dinuclear AgPt" complex, ${ }^{7}$ and adopts distorted tetrahedral geometry giving an angle between two $\mathrm{AgPt}_{2}$ planes of $87.8^{\circ}$. The $\mathrm{Ag}(\mathrm{I})$ ion bridges one of three Pt-Pt bonds in each triplatinum complex at the least hindered environment surrounded by the two methylene bridges in the two NHC ligands. The $\mathrm{Ag}(\mathrm{I})$ ion nearly locates on the $\mathrm{Pt}_{3}$ plane with an angle between the $\mathrm{Pt}_{3}$ and $\mathrm{AgPt}_{2}$ planes of $14.5^{\circ}$ and two $\mathrm{Pt}_{3}$ planes are almost perpendicular to each other $\left(87.4^{\circ}\right)$. Similar reactions of $\mathrm{Ag}(\mathrm{I})$ ion and triplatinum complexes were reported for $\left[\left\{\mathrm{Pt}_{(}\left(\mathrm{PR}_{3}\right)\right\}_{3}(\mu-\mathrm{CO})_{3}\right]$ affording heptanuclaer clusters with $\mathrm{Pt}(0)$ centres, $\left[\mathrm{Ag}\left\{\left[\mathrm{Pt}\left(\mathrm{PR}_{3}\right)\right]_{3}(\mu-\mathrm{CO})_{3}\right\}_{2}\right]^{+}\left(\mathrm{R}=i \mathrm{Pr},{ }^{8} t\right.$ $\left.\mathrm{Bu}_{2} \mathrm{Ph}^{9}\right)$. However, the structurally characterised $\left[\mathrm{Ag}\left\{\left[\mathrm{Pt}\left(\mathrm{PiPr}_{3}\right)\right]_{3}(\mu-\mathrm{CO})_{3}\right\}_{2}\right]^{+}$has a sandwich structure, in which the $\mathrm{Ag}(\mathrm{I})$ ion locates in between two parallel $\mathrm{Pt}_{3}$ planes affording six $\mathrm{Ag}-\mathrm{Pt}$ bonds. ${ }^{8} \mathrm{~A}$ tetranuclear $\mathrm{AgPt}_{3}$ cluster composed of a $\mathrm{Pt}_{3}{ }_{3}$ unit has similar $\mathrm{Ag}-\mathrm{Pt}$ bonds with a halfsandwich type structure. ${ }^{10} \mathrm{~A}$ trinuclear $\mathrm{Pt}_{2}{ }_{2} \mathrm{Ag}$ complex was also reported showing a longer $\mathrm{Ag}-\mathrm{Pt}$ bond (3.118(3) $\AA$ ) probably reflecting the lower oxidation state of the $\mathrm{Pt}(\mathrm{I})$ centre. ${ }^{11}$

Formation of four $\mathrm{Ag}-\mathrm{Pt}$ bonds in the reaction of $\mathrm{Ag}(\mathrm{I})$ ion and 48-CVE complex $[\mathbf{1}]^{2+},\left[\{\mathrm{Pt}(\text { bisNHC-C1 })\}_{3}\left(\mu_{3}-\mathrm{S}\right)_{2}\right]^{2+}$, bearing closed-shell $\mathrm{Pt}$ centres with three $\mathrm{Pt}-\mathrm{Pt}$ bonds can be understood using the simple traditional CVE counting. Addition of $\mathrm{d}^{10} \mathrm{Ag}(\mathrm{I})$ ion to two 48-CVE complexes with making four metal-metal bonds, which can be counted as eight electrons on the electron counting, affords the closed-shell Ag centre. Similar consideration based on the electron counting can be applied for previously reported heptanuclear $\mathrm{Os}_{3}-\mathrm{Ag}$ $\mathrm{Os}_{3}{ }^{12}$ and $\mathrm{Rh}_{3}-\mathrm{Ag}-\mathrm{Rh}_{3}{ }^{13}$ clusters, which were obtained by the reactions of an $\mathrm{Ag}(\mathrm{I})$ source and the 48-CVE complexes, $\left[\mathrm{Os}_{3}(\mathrm{CO})_{10}(\mu-\mathrm{Cl})\right]^{-}$or $\left[(\mathrm{RhCp})_{3}(\mu-\mathrm{CO})_{3}\right]$, affording $\left[\mathrm{Ag}\left\{\mathrm{Os}_{3}(\mathrm{CO})_{10}\right.\right.$ 
$\left.(\mu-\mathrm{Cl})\}_{2}\right]^{-}$or $\left[\mathrm{Ag}\left\{(\mathrm{RhCp})_{3}(\mu-\mathrm{CO})_{3}\right\}_{2}\right]^{+}$, respectively, accompanied by the formation of four $\mathrm{Ag}-\mathrm{M}$ bonds.

It is noteworthy that the $\mathrm{Ag}(\mathrm{I})$ ion does not attack the sulfide ligands but the Pt centres of complex $[\mathbf{1}]^{2+}$ although transition metals have high affinity with sulfide ligands in some transition metal clusters. For examples, reactions of $\left[\mathrm{Ru}_{4}(\mathrm{CO})_{11}\left(\mu_{4}-\mathrm{S}\right)_{2}\right]$ with $\left[\mathrm{W}(\mathrm{CO})_{5}\left\{\mathrm{C}(\mathrm{Ph}) \mathrm{NMe}_{2}\right\}\right],{ }^{14} \quad\left[\mathrm{HFe}_{2} \mathrm{Co}\right.$ $\left.(\mathrm{CO})_{9}\left(\mu_{3}-\mathrm{S}\right)\right]$ with $\left[\mathrm{FeCp}^{\prime}(\mathrm{CO})_{2} \mathrm{Cl}\right]^{15}$ and $\left[\mathrm{Mn}_{3}(\mathrm{CO})_{9}\left(\mu_{3}-\mathrm{S}\right)_{2}\right]^{-}$with $\left[\mathrm{Cr}(\mathrm{CO})_{6}\right]^{16}$ afforded $\left[\left\{\mathrm{Ru}_{4}(\mathrm{CO})_{10}\left\{\mathrm{C}(\mathrm{Ph}) \mathrm{NMe}_{2}\right\}\left(\mu_{4}-\mathrm{S}\right)\right\}\left(\mu_{5^{-}}\right.\right.$ S) $\left.\left\{\mathrm{W}(\mathrm{CO})_{5}\right\}\right],\left[\left\{\mathrm{Fe}_{2} \mathrm{Co}(\mathrm{CO})_{9}\right\}\left(\mu_{4}-\mathrm{S}\right)\left\{\mathrm{FeCp}^{\prime}(\mathrm{CO})_{2}\right\}\right]$ and $\left[\left\{\mathrm{HMn}_{3}(\mathrm{CO})_{9}\right.\right.$ $\left.\left.\left(\mu_{3}-\mathrm{S}\right)\right\}\left(\mu_{4}-\mathrm{S}\right)\left\{\mathrm{Cr}(\mathrm{CO})_{5}\right\}\right]^{2-}$, respectively, accompanied by additional $\mathrm{M}-\mathrm{S}$ bond formation showing such high affinity of metals with sulfides. Furthermore, $\mathrm{Ag}(\mathrm{I})$ ions abstract sulfides from dirhodium complexes. ${ }^{17}$ These facts revealed that additional metal-metal bond formation is more preferred than metal-sulfide bond formation in the reaction of $\mathrm{Ag}(\mathrm{I})$ and $[1]^{2+}$ probably due to stabilised electron configuration of the cluster core. Heptanuclear cluster [2 $]^{5+}$ is the first example for this type of heptanuclear clusters bearing $\mathrm{Pt}_{3} \mathrm{~S}_{2}$ units.

${ }^{1} \mathrm{H}$ NMR spectrum of the heptanuclear cluster at room temperature showed six sets of sharp signals for the bis-NHC ligands (Fig. 4(c)). This result shows that two kinds of the triplatinum units with the $C_{s}$ symmetry exist. As these ${ }^{1} \mathrm{H}$ NMR signals were going to merge as temperature rose (Fig.4), the $\mathrm{Pt}_{3} \mathrm{~S}_{2}-\mathrm{Ag}-\mathrm{Pt}_{3} \mathrm{~S}_{2}$ framework of the heptanuclear cluster, which was observed in the solid state, maintains intact in solution

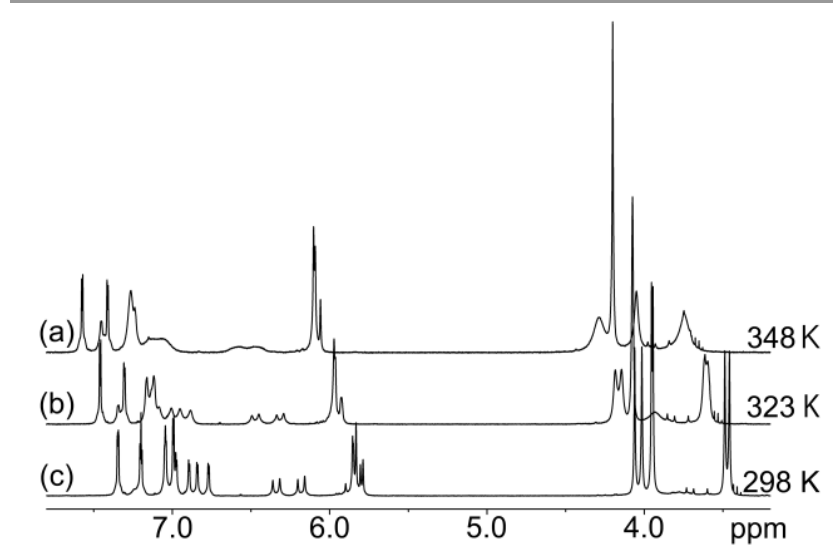

Fig. $4{ }^{1} \mathrm{H}$ NMR spectra of heptanuclear cluster $[2]^{5+}$ in $\mathrm{CD}_{3} \mathrm{CN}$ at (a) $348 \mathrm{~K}$, (b) $323 \mathrm{~K}$ and (c) $298 \mathrm{~K}$.
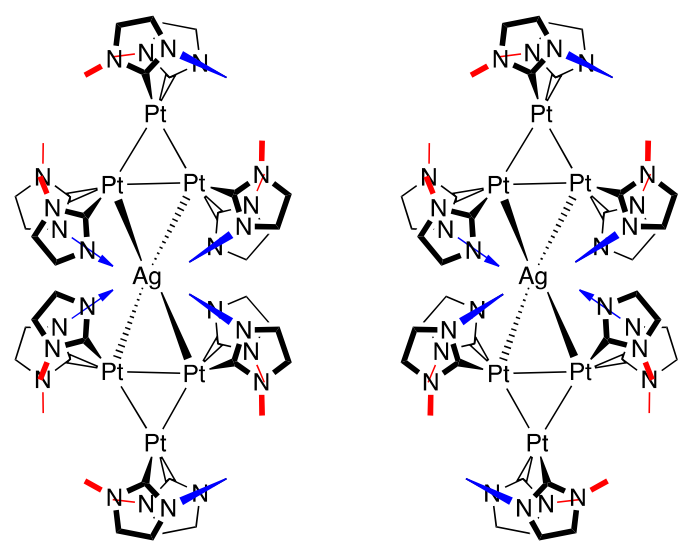

Scheme 4 Two possible isomers of heptanuclear cluster $[\mathbf{2}]^{5+}$. and there are two isomers attributed to the orientation of the triplatinum units (Scheme 4). Additionally, the sharp ${ }^{1} \mathrm{H}$ NMR signals for $[2]^{5+}$ at room temperature suggests that the flapping motion of the bis-NHC ligands is slower than ${ }^{1} \mathrm{H}$ NMR time scale probably due to the Ag-Pt bond formation.

\section{Conclusions}

Formation of a heptanuclear cluster bearing a $\mathrm{Pt}_{3}-\mathrm{Ag}-\mathrm{Pt}_{3}$ core was demonstrated using a triplatinum sulfide complex with bis-N-heterocyclic carbene ligands. Structural analysis of the cluster revealed that the $\mathrm{Ag}(\mathrm{I})$ ion bound to the Pt-Pt bonds located at the least hindered place. The formation of the Ag-Pt bonds is well-explained using traditional cluster valence electron counting. Because the triplatinum complex potentially captures $\mathrm{d}^{10}$ metals such as $\mathrm{Cd}^{2+}$ and $\mathrm{Hg}^{2+}$, investigation of reactions with $\mathrm{d}^{10}$ metals and electrochemical properties of the complexes is in progress toward sensing such metal ions.

\section{Conflicts of interest}

There are no conflicts to declare.

\section{Notes and references}

\# This work was partly supported by JSPS KAKENHI Grant Number JP17K05814.

1 P. Atkins, T. Overton, J. Rourke, M. Weller and F. Armstrong, Shriver \& Atkins Inorganic Chemistry, 4th ed., Oxford University Press: Oxford, U.K., 2006; pp 557-558.

2 A. Venturelli and T. B. Rauchfuss, J. Am. Chem. Soc., 1994, 116, 4824-4831.

3 Y. Kushi, H. Nagao, T. Nishioka, K. Isobe and K. Tanaka, Chem. Lett., 1994, 2175-2178; Y. Kushi, H. Nagao, T. Nishioka, K. Isobe and K. Tanaka, J. Chem. Soc., Chem. Commun., 1995, 1223-1224; K. Tanaka, Y. Kushi, K. Tsuge, K. Toyohara, T. Nishioka and K. Isobe, Inorg. Chem., 1998, 37, 120-126.

4 Y. Maeda, H. Hashimoto and T. Nishioka, Dalton Trans., 2012, 41, 12038-12047.

5 Y. Maeda, H. Hashimoto, I. Kinoshita and T. Nishioka, Inorg. Chem., 2014, 53, 661-663.

6 Y. Maeda, H. Hashimoto, I. Kinoshita and T. Nishioka, Inorg. Chem., 2015, 54, 448-459.

7 A. V. Artem'ev, M. I. Rogovoy, D. G. Samsonenko and M. I. Rakhmanova, Inorg. Chem. Commun. 2020, DOI: 10.1016/j.inoche.2020.107862.

8 A. Albinati, K.-H. Dahmen, A. Tongni and L. M. Venanzi, Angew. Chem. Int. Ed., 1985, 24, 766-767.

9 C. Couture, D. H. Farrar, D. S. Fisher and R. R. Gukathasan, Organometallics, 1987, 6, 532-536.

10 P. Braunstein, S. Freyburger and O. Bars, J. Organomet. Chem. 1988, 352, C29-C33.

11 T. Tanase, H. Toda and Y. Yamamoto, Inorg. Chem. 1997, 36, 1571-1577.

12 C. E. Cooke, T. Ramnial, M. C. Jennings, R. K. Pomeroy and J. A. C. Clyburne, Dalton Trans., 2007, 1755-1758; C. E. Cooke, M. C. Jennings, M. J. Katz, R. K. Pomeroy and J. A. C. Clyburne, Organometallics, 2008, 27, 5777-5799.

13 M. I. Rybinskaya, A. R. Kudinov, D. V. Muratov, N. P. Gambaryan, I. V. Stankevich and A. L. Chistyakov, J. Organomet. Chem., 1991, 413, 419-426. 
14 R. D. Adams, J. E. Babin and J.-G. Wang, Polyhedron,1989, 8, 2351-2358.

15 W.-H. Sun, H.-Q. Wang, Q.-F. Zhou and S.-Y. Yang, Polyhedron, 1994, 13, 851-853.

16 M. Shieh, C.-Y. Miu, K.-C. Huang, C.-F. Lee and B.-G. Chen, Inorg. Chem., 2011, 50, 7735-7748.

17 T. Nishioka, V. Yu. Kukushkin, K. Isobe and A. V. de Miguel, Inorg. Chem., 1994, 33, 2501-2502. 